\title{
Revisiting the Psychometric Properties of Market Orientation Framework in an Emerging Economy: a Case-Study of Botswana'S Small Service Firms
}

\author{
Olumide Olasimbo Jaiyeoba, \\ Department of Marketing, Faculty of Business \\ University of Botswana
}

Received: July 18, 2013 Accepted: August 9, 2013

doi:10.5296/ber.v3i2.4686 URL: http://dx.doi.org/10.5296/ber.v3i2.4686

\begin{abstract}
While much empirical work has centered on market orientation, an investigation of the psychometric properties of Market Orientation (MO) scale items as adapted from Kholi and Jaworski,(1993), in the Botswana context has been under researched. A reliable scale with demonstrated content and convergent validity is developed in this empirical study and the impact of market orientation efficiency on economic and noneconomic performance of service firms is evaluated based on key informant data drawn from sampled service firms in Botswana. Top management emphasis, centralization, market turbulence, intelligence generation, dissemination and responsiveness, business performance, customer satisfaction, technological turbulence, market based reward system, and overall market orientation were found to be reliable and valid antecedents and consequences of market orientation. The study results using factor analysis approach, therefore offer one more robustness in the applicability of MO scale items among Botswana's small service firms by ensuring that managers use psychometrically valid scale items to generate, disseminate and respond to information with a view to improving performance of small service firms.
\end{abstract}

Keywords: Psychometric Properties of Market orientation, Factor Analysis Approach, Small Service Firms, Business Performance and Botswana.

\section{Introduction}

The development of coherent, robust and generalizable theory requires a base of well defined constructs (Summers, 2001). While much empirical work has centered on market orientation, an investigation of the psychometric properties of MO scale items as adopted from Kholi and 
Jaworski, (1993), in the Botswana context has been under researched. This study therefore intends to investigate the reliability and validity of market orientation framework in Botswana. A reliable scale with demonstrated content and convergent validity is developed and the impact of market orientation efficiency on economic and noneconomic performance of service firms is evaluated based on key informant data drawn from sampled service firms in Botswana. Gilliam and Voss, (2013) postulated that if researchers expend the necessary resources to properly define constructs during early stages of research projects, this foundation will be strong and able to support expansive theories. Gilliam and Voss,(2013) concluded that construct definitions prevent scientific discussion from devolving into babel Thus, the process of construct definition is a critically important and complex task facing marketing researchers not only in developed world, but also in the developing economy.

\section{Objective of the Study}

To investigate the psychometric properties of prominent market orientation factors influencing the economic and non economic performance of small service firms in Botswana using Factor analysis Approach.

\section{Literature Review}

A scale is said to have content validity, if the scale items form a representative sample of the theoretical domain of the construct (Churchill, 1979; Bagozzi and Foxall, 1995). Babin and Svensson, (2012), thus identified the year 1979, as the year of breakthrough from the paradigm of single item structures and metric measures, as well as the lack of reliability estimates of used constructs in marketing research to a change towards the use of multi items structures and metric measures and reliability theory in marketing research of human perception, behaviour or phenomenon. After this time, the reliability concept became a routine part of the results sections of marketing research articles. Infact, Churchill,(1979), wrote about an emerging paradigm for developing measures of marketing constructs, while Peter,(1979), cited in Babin and Svensson (2012), presented a reliability review of psychometric basics and marketing practices. Indeed, many otherwise well executed projects fail to have the impact they should due to poor construct definitions (Churchill,1979).Bearden and Netemeyer, (1999), thus provided extensive reviews of numerous multi item structures and metric measures in extant marketing research literature that have considered the estimates of validity and reliability. Therefore, the goal of measurement development is to produce instruments that carry meaning and are useful for describing and explaining phenomena. This empirical study thus lend credence to the need for measurement development. Psychometricians consider three criteria in their assessment of the quality of measures. The first is the unidimensionality of the scale. This is concerned with the degree to which the items in the scale load on a single factor Gerbing and Anderson,(1988). This aspect of a measurement is important because, theory development and testing requires that a single idea be represented by the measure to allow for subsequent testing for correlations with other constructs or differences between groups. A second aspect of good measures is that they are reliable. This characteristic deals with the stability of the measures over time and the internal consistency of answers on measures containing multiple items, Rust and Cooil, (1994). This empirical study, thus examine the content validity, dimensionality, 
coefficient alpha, with a focus on the coherence or interrelatedness of the psychometric properties of small service firms in Botswana. The third indicator of strong measures is validity. This is concerned with the degree to which the measure in fact represents the construct domain (Churchill, 1979). Thus, at the heart of repeatability and standardization are the measurement properties of reliability and validity, which this study intends to explicate.

Mowen \& Voss, (2008); Rossiter, (2002), analogously postulated that some authors have suggested that researcher concentration on operationalisation and statistical analysis have distracted attention from construct definition. This assertion created the need for this empirical study among Botswana's small service firms. Gilliam and Voss, (2010), therefore posited that a contributing factor is the lack of understanding of an implementable construct definition process within the extant psychometric literature. Mackenzie, (2003), thus suggested that poor construct conceptualization and definition plagues many manuscripts submitted for review. Mackenzie, (2003), noted the impossibility of accurately specifying theoretical relations between two constructs that lack precise meanings. Summers,(2001), concluded that the development of coherent, robust and generalizable theory requires a base of well defined constructs. Hunt (1991) and Teas and Palan (1997) thus suggested the use of formalized language in definitions to reduce ambiguity and vagueness in psychometric competence. Contrastingly, Williamson, (1994), postulated that while the use of formalized language may facilitate some aspects of the construct definition effort, it introduces a number of problems that have prevented its widespread adoption. Rejecting this psychometric paradigm, Rossiter, (2002), suggested that being far more specific in regard to the time and place where the construct is applicable will aid in construct definition.

\section{Research Methodology}

The study employed a snowball sample of managers and business owners in the small service firm domain within Gaborone and its environs. The reason for opting for non-probability rather than probability sampling was that the sampling frame of the key informants was not available. In addition, the study was confirmatory in nature in order to improve the understanding of organizational market orientation behaviour in Botswana context. The final pool of small service firms to whom questionnaires was sent totaled 400. Eventually, only 249 (constituting over $60 \%$ response rate) usable questionnaires were returned by the respondents. The questionnaire was pretested prior to collecting data and respondents were asked to identify items they found unclear, ambiguous or confusing. As a result of the pretest, minor adjustments were made to the questionnaire. Data was collected between mid July 2012 to Mid October 2012.The service firms sampled included tourism firms (5.6\%); transport firms (10.7\%); financial services subsector (9.4\%); consulting services (19.2\%) and other services subsector accounting for $(55.1 \%)$. The majority of the respondent personnel were managers, accounting for about $50 \%$ of the total. This suggests that most respondents were sufficiently experienced to be able to provide meaningful response to broader policy issues relating to market orientation. After comparing the responses of the early and late respondents, on a number of characteristics, no significant difference was found suggesting that the sample is free from response bias. The sample size and the response rate are consistent with related studies. 
The questionnaire and scale measures (MARKOR Scale) were adapted from Kholi \& Jaworski, (1993) constructs. The items in the questionnaire were measured with the aid of a Five point Likert type Scale. The internal antecedents were measured by items adapted from Jaworski \& Kholi, (1993). External antecedents were adopted from Jaworski \& Kholi, (1993) and Gray et $a l,(1998)$ respectively. Reliability analysis was conducted on all the multi items scales to check the internal consistency of the scales. This study adopted a cut off of 0.5 for Cronbach's Coefficient following Nunally (1978).Using 0.5 as the cut off is not without precedent. It has been adopted in related studies (Blankson \& Stoke, 2002; Blankson \& Cheng, 2005).

\section{Results and Discussion}

In order to ascertain whether the measures retained construct validity (i.e. measure what they are supposed to), an exploratory factor analysis using principal components and varimax rotation technique was conducted to examine the underlying dimension of MO construct. In determining the factors, common decision rules employed in empirical research was applied: minimum Eigen value of 1; KMO measure of sampling adequacy greater than 0.5 and Bartlett's test of sphericity are significant, which indicate that the items are appropriate for factor analysis. This analysis thus test for the distinctiveness of internal and external antecedents, overall market orientation, as well as economic and non economic performance constructs and validate the measurement models (See Tables 1-6 below). This empirical study thus exhibit psychometric equivalence by providing acceptable levels of reliability, variance extracted, and both discriminant and nomological validity.

All factor loadings included in this study were statistically significant at the 0.01 level and exceed the arbitrary 0.5 standard. Thus, these measures demonstrate adequate convergent validity. All of the cross-construct correlations were significantly different from 1.0, which suggests that discriminant validity was present. In general, these results provide support for construct validity for the measures included in this study. As displayed in the Tables 1-6 below, the estimated standard loadings ranged from 0.50- 0.92. These are above the accepted cut-off value of 0.50 (Teo \& King 1996). Finally, all items loaded higher on their respective constructs than on others, thus providing strong support for discriminant validity. The validity of the scale therefore explicates the unidimensionality of the components of each scale (Gerbing \& Anderson, 1998) with a principal component factor analysis. These findings thus reduce the plausibility of threat to validity in this study, by presenting a description of MO construct and explicative MO model, grounded on the marketing concept.

Table 1. Psychometric properties of market orientation awareness, intelligence generation and dissemination:

\begin{tabular}{|c|c|c|c|c|c|c|}
\hline & $\begin{array}{c}\text { Factor } \\
\text { Loading }\end{array}$ & $\begin{array}{c}\text { Eigen } \\
\text { Value }\end{array}$ & $\begin{array}{c}\text { \% } \\
\text { Variance }\end{array}$ & KMO & $\begin{array}{c}\text { Bartlett's } \\
\text { test }\end{array}$ & df \\
\hline $\begin{array}{c}\text { Factor 1: Market orientation awareness } \boldsymbol{\alpha}= \\
\mathbf{0 . 7 1 , ~} \text { F-test } \mathbf{5 1 . 0 2 9} \mathbf{p}<\mathbf{0 . 0 1}\end{array}$ & & 2.174 & 54.349 & $70.6 \%$ & 198.495 & $6 \mathrm{p}<0.01$ \\
\hline $\begin{array}{c}\text { We encourage customer comments and } \\
\text { complaints because they help us to do better job }\end{array}$ & 0.760 & & & & & \\
\hline $\begin{array}{c}\text { We have a strong commitment to our customer's } \\
\text { need }\end{array}$ & 0.809 & & & & & \\
\hline We are always looking at ways to create & 0.787 & & & & \\
\hline
\end{tabular}




\begin{tabular}{|c|c|c|c|c|c|c|}
\hline customer value in our services & & & & & & \\
\hline $\begin{array}{l}\text { We measures customer's satisfaction on a regular } \\
\text { basis }\end{array}$ & 0.568 & & & & & \\
\hline $\begin{array}{l}\text { Factor 2: Intelligence generation } \alpha=0.630, \\
\text { F-test }=141.351 \mathrm{p}<0.01\end{array}$ & & 2.948 & 59.948 & $66.9 \%$ & 469.771 & $45 \mathrm{p}<0.01$ \\
\hline $\begin{array}{l}\text { In this business, we meet with customers at least } \\
\text { once a year to find out their future needs }\end{array}$ & 0.609 & & & & & \\
\hline $\begin{array}{l}\text { Individuals/Employees from our business } \\
\text { interact directly with customers to learn how to } \\
\text { serve them better }\end{array}$ & 0.468 & & & & & \\
\hline $\begin{array}{l}\text { We often talk with or survey those who can } \\
\text { influence our end users 'purchases } \\
\text { (e.g.,retailers,distributors) }\end{array}$ & 0.653 & & & & & \\
\hline $\begin{array}{c}\text { In our business unit, information on our } \\
\text { competitors is generated independently by our } \\
\text { business }\end{array}$ & 0.589 & & & & & \\
\hline $\begin{array}{l}\text { We collect industry information by informal } \\
\text { means (e.g., lunch with industry friends, talks } \\
\text { with trade partners). }\end{array}$ & 0.632 & & & & & \\
\hline $\begin{array}{c}\text { In this business, we do a lot of in house market } \\
\text { research }\end{array}$ & 0.594 & & & & & \\
\hline $\begin{array}{c}\text { We survey our end users at least once a year to } \\
\text { assess how they perceive the quality of our } \\
\text { products }\end{array}$ & 0.705 & & & & & \\
\hline $\begin{array}{l}\text { We periodically review the likely effect of } \\
\text { changes in our business environment (e.g., } \\
\text { regulation) on customer }\end{array}$ & 0.515 & & & & & \\
\hline $\begin{array}{c}\text { Factor 3: Intelligence dissemination } \alpha=0.60, \\
\text { F-test }=89.409 \mathrm{p}<0.01\end{array}$ & & 2.641 & 44.016 & $72.4 \%$ & 317.927 & $15 \mathrm{p}<0.01$ \\
\hline $\begin{array}{l}\text { In our business, we have business meetings at } \\
\text { least once a quarter to discuss market trends and } \\
\text { developments }\end{array}$ & 0.703 & & & & & \\
\hline $\begin{array}{c}\text { Marketing personnel in our business spend time } \\
\text { discussing customers future needs with other } \\
\text { employees }\end{array}$ & 0.748 & & & & & \\
\hline $\begin{array}{c}\text { Data on customer satisfaction are disseminated at } \\
\text { all levels in this business on a regular basis }\end{array}$ & 0.783 & & & & & \\
\hline $\begin{array}{l}\text { If anything important happens to a major } \\
\text { customer or market, the whole business knows } \\
\text { about it in a short period }\end{array}$ & 0.716 & & & & & \\
\hline $\begin{array}{l}\text { A lot of informal talk in this business unit } \\
\text { concerns our competitors' tactics or strategies }\end{array}$ & 0.567 & & & & & \\
\hline
\end{tabular}

Table 2. Psychometric properties of intelligence responsiveness and top management emphasis

\begin{tabular}{|c|c|c|c|c|c|c|}
\hline & $\begin{array}{c}\text { Factor } \\
\text { Loading }\end{array}$ & $\begin{array}{l}\text { Eigen } \\
\text { Value }\end{array}$ & $\begin{array}{c}\% \\
\text { Variance }\end{array}$ & KMO & $\begin{array}{c}\text { Bartlett's } \\
\text { test }\end{array}$ & df \\
\hline $\begin{array}{c}\text { Factor } 4 \text { :Intelligence responsiveness } \alpha=0.55, \text { F-test }= \\
116.689 \mathrm{p}<0.01\end{array}$ & & 3.616 & 55.83 & $75.00 \%$ & 688.427 & $\begin{array}{c}91 \\
\mathrm{p}<0.01\end{array}$ \\
\hline $\begin{array}{l}\text { We periodically review our product development efforts to } \\
\text { ensure that they are in line with what customers want }\end{array}$ & 0.602 & & & & & \\
\hline $\begin{array}{l}\text { When we find that customers would like us to modify a } \\
\text { product, the business involved make concerted efforts to do } \\
\text { so }\end{array}$ & 0.503 & & & & & \\
\hline The different activities in this business are well coordinated & 0.671 & & & & & \\
\hline
\end{tabular}




\begin{tabular}{|c|c|c|c|c|c|c|}
\hline $\begin{array}{l}\text { Principles of market segmentation(market or products we are } \\
\text { dealing with) drive new product development efforts in this } \\
\text { business unit }\end{array}$ & 0.556 & & & & & \\
\hline $\begin{array}{c}\text { When we find that customers are unhappy with the quality of } \\
\text { our service, we take corrective action immediately }\end{array}$ & 0.545 & & & & & \\
\hline $\begin{array}{l}\text { Factor } 5 \text { :Top management emphasis } \alpha=0.730, \text { F-test }= \\
\qquad 22.147 \mathrm{p}<0.01\end{array}$ & & 2.238 & 55.953 & $69.20 \%$ & 238.845 & $6 \mathrm{p}<0.01$ \\
\hline $\begin{array}{l}\text { In this business, manager/owner repeatedly tell employees } \\
\text { that this business survival depends on its adapting to market } \\
\text { trends }\end{array}$ & 0.809 & & & & & \\
\hline $\begin{array}{l}\text { Managers/owners often tell employees to be sensitive to the } \\
\text { activities of our competitors }\end{array}$ & 0.790 & & & & & \\
\hline $\begin{array}{l}\text { Managers keep telling people around here that they must gear } \\
\text { up now to meet customers future needs }\end{array}$ & 0.841 & & & & & \\
\hline $\begin{array}{l}\text { According to managers/owners here, serving customers is the } \\
\text { most important thing our business does }\end{array}$ & 0.501 & & & & & \\
\hline
\end{tabular}

Table 3. Psychometric properties of risk aversion, centralization, and formalization

\begin{tabular}{|c|c|c|c|c|c|c|}
\hline & $\begin{array}{l}\text { Factor } \\
\text { Loading }\end{array}$ & $\begin{array}{l}\text { Eigen } \\
\text { Value }\end{array}$ & $\begin{array}{c}\% \\
\text { Variance }\end{array}$ & KMO & $\begin{array}{c}\text { Bartlett's } \\
\text { test }\end{array}$ & df \\
\hline Factor 6 :Risk aversion $\alpha=0.53, F$-test $=3.439 p<0.05$ & & 1.736 & 53.403 & $60.0 \%$ & 99.413 & $6 \mathrm{p}<0.01$ \\
\hline $\begin{array}{l}\text { Managers/owners in this business believe that higher financial } \\
\text { risks are worth taking for higher rewards }\end{array}$ & 0.554 & & & & & \\
\hline $\begin{array}{c}\text { Managers/owners in this business like to take big financial } \\
\text { risks }\end{array}$ & 0.827 & & & & & \\
\hline $\begin{array}{l}\text { Managers here encourage the development of innovating } \\
\text { business strategies, knowing well that some will fail }\end{array}$ & 0.784 & & & & & \\
\hline $\begin{array}{c}\text { Formal business education is the key requirement of the } \\
\text { owner/ manager in our business }\end{array}$ & 0.753 & & & & & \\
\hline Factor 7: Centralization $\alpha=0.880$, F-test $=12.328 p<0.01$ & & 2.947 & 73.669 & $78.2 \%$ & 602.255 & $6 \mathrm{p}<0.01$ \\
\hline $\begin{array}{c}\text { There can be little action taken here until a supervisor } \\
\text { approves a decision }\end{array}$ & 0.743 & & & & & \\
\hline $\begin{array}{l}\text { Even small matters have to be referred to someone higher for } \\
\text { a final decision }\end{array}$ & 0.911 & & & & & \\
\hline I have to ask my boss before I do almost anything & 0.922 & & & & & \\
\hline Any decision I make has to be my boss approval & 0.845 & & & & & \\
\hline Factor 8: Formalization $\alpha=0.512$, F-test $=18.396 p<0.01$ & & 1.293 & 43.106 & $50.3 \%$ & 20.932 & $3 \mathrm{p}<0.01$ \\
\hline $\begin{array}{l}\text { For most of the things in our business, it is within the authority } \\
\text { of those(owner/manager), who are responsible for them to } \\
\text { decide how they will be done }\end{array}$ & 0.731 & & & & & \\
\hline $\begin{array}{c}\text { The employees in this business are constantly monitored for } \\
\text { rules violation }\end{array}$ & 0.802 & & & & & \\
\hline
\end{tabular}

Table 4. Psychometric properties of Market based reward system, interpersonal connectedness, interpersonal conflict and competition

\begin{tabular}{|c|c|c|c|c|c|c|}
\hline & $\begin{array}{c}\text { Factor } \\
\text { Loading }\end{array}$ & $\begin{array}{l}\text { Eigen } \\
\text { Value }\end{array}$ & $\begin{array}{c}\% \\
\text { Variance }\end{array}$ & КMO & $\begin{array}{c}\text { Bartlett } \\
\text { 'test }\end{array}$ & df \\
\hline $\begin{array}{l}\text { Factor } 9 \text { : Market based reward system } \alpha=0.782, \text { F-test }= \\
\qquad 7.135 p<0.01\end{array}$ & & 2.420 & 60.492 & $76.8 \%$ & 265.436 & $6 p<0.01$ \\
\hline $\begin{array}{l}\text { Employees in this business get recognized for being sensitive } \\
\text { to competitive moves }\end{array}$ & 0.740 & & & & & \\
\hline
\end{tabular}




\section{Macrothink}

Business and Economic Research

ISSN 2162-4860

2013, Vol. 3, No. 2

\begin{tabular}{|c|c|c|c|c|c|c|}
\hline $\begin{array}{l}\text { Customer satisfaction assessments influence owner/managers } \\
\qquad \text { pay in this business }\end{array}$ & 0.847 & & & & & \\
\hline $\begin{array}{l}\text { Formal rewards (e.g., pay rise, promotion) are forthcoming to } \\
\text { anyone who consistently provides good market } \\
\text { intelligence/information }\end{array}$ & 0.789 & & & & & \\
\hline $\begin{array}{l}\text { Salespeople's performance in this business is measured by the } \\
\text { strength of relationships they build with customers }\end{array}$ & 0.729 & & & & & \\
\hline $\begin{array}{l}\text { Factor } 10: \text { Interpersonal conflict } \alpha=0.62, \text { F-test }=176.980 \\
\qquad p<0.01\end{array}$ & & 1.878 & 37.564 & $59.0 \%$ & 122.742 & $10 \mathrm{p}<0.01$ \\
\hline Most employees in this business get along well with each other & 0.727 & & & & & \\
\hline $\begin{array}{l}\text { Employees from this business feel that the goals of their } \\
\text { respective business are in harmony with each other }\end{array}$ & 0.669 & & & & & \\
\hline There is little or no interpersonal conflict in this company & 0.515 & & & & & \\
\hline $\begin{array}{l}\text { Factor } 11 \text { : Interpersonal connectedness } \alpha=0.81, \text { F-test }= \\
\qquad 4.373 p<0.01\end{array}$ & & 2.532 & 63.304 & $76.0 \%$ & 316.486 & $6 \mathrm{p}<0.01$ \\
\hline $\begin{array}{l}\text { In this business, regardless of their rank or position, it is easy } \\
\text { to talk to anyone needed }\end{array}$ & 0.752 & & & & & \\
\hline $\begin{array}{l}\text { There is ample opportunity for informal hall talk among } \\
\text { individuals in this business }\end{array}$ & 0.771 & & & & & \\
\hline $\begin{array}{l}\text { In this business, employees feel comfortable calling each other } \\
\text { when the need arises }\end{array}$ & 0.845 & & & & & \\
\hline People in this business are quite accessible to one another & 0.812 & & & & & \\
\hline Factor 12 : Competition $\alpha=0.77$, F-test $=45.422 p<0.01$ & & 3.092 & 44.171 & $78.3 \%$ & 511.320 & $21 \mathrm{p}<0.01$ \\
\hline We regularly monitor our competitors marketing efforts & 0.763 & & & & & \\
\hline $\begin{array}{l}\text { We frequently collect marketing data/information on our } \\
\text { competitors to help direct our marketing plans }\end{array}$ & 0.789 & & & & & \\
\hline $\begin{array}{l}\text { Our salespeople are instructed to monitor and report on } \\
\text { competitor activity }\end{array}$ & 0.815 & & & & & \\
\hline We respond rapidly to competitors actions & 0.744 & & & & & \\
\hline There are many promotion wars in our business. & 0.588 & & & & & \\
\hline Price competition is a hallmark of our business. & 0.592 & & & & & \\
\hline Our competitors are relatively weak & 0.584 & & & & & \\
\hline
\end{tabular}

Table 5. Psychometric properties of market turbulence, general economy, organizational commitment, esprit de corps and business performance.

\begin{tabular}{|c|c|c|c|c|c|c|}
\hline & $\begin{array}{c}\text { Factor } \\
\text { Loading }\end{array}$ & $\begin{array}{l}\text { Eigen } \\
\text { Value }\end{array}$ & $\begin{array}{c}\% \\
\text { Variance }\end{array}$ & KMO & $\begin{array}{c}\text { Bartlett's } \\
\text { test }\end{array}$ & df \\
\hline $\begin{array}{l}\text { Factor } 13 \text { : Market Turbulence } \alpha=0.529, \text { F-test }=9.188 \\
\qquad<<0.01\end{array}$ & & 1.894 & 47.347 & $67.8 \%$ & 110.611 & $6 \mathrm{p}<0.01$ \\
\hline $\begin{array}{c}\text { In our kind of business, customer's product preferences } \\
\text { change quite a bit over time }\end{array}$ & 0.717 & & & & & \\
\hline Our customers tend to look for new product all the time & 0.767 & & & & & \\
\hline $\begin{array}{l}\text { We are witnessing demand for our products and services from } \\
\text { customers who never bought them before }\end{array}$ & 0.616 & & & & & \\
\hline
\end{tabular}




\section{MInstitute Macrothink $_{\text {Int }}$}

Business and Economic Research

ISSN 2162-4860

2013, Vol. 3, No. 2

\begin{tabular}{|c|c|c|c|c|c|c|}
\hline $\begin{array}{l}\text { Sometimes our customers are price sensitive, but on other } \\
\text { occasions, price is relatively unimportant }\end{array}$ & 0.641 & & & & & \\
\hline $\begin{array}{l}\text { Factor } 14: \text { General Economy } \alpha=0.647, \text { F-test }=74.412 \\
\qquad p<0.01\end{array}$ & & 1.437 & 47.895 & $51.0 \%$ & 47.384 & $3 \mathrm{p}<0.01$ \\
\hline $\begin{array}{l}\text { The customers in our business are likely to be value } \\
\text { conscious }\end{array}$ & 0.820 & & & & & \\
\hline $\begin{array}{l}\text { Our business is more responsive to customer needs in order to } \\
\text { offer good value for money }\end{array}$ & 0.831 & & & & & \\
\hline $\begin{array}{l}\text { Factor } 15: \text { Organizational commitment } \alpha=0.62, \text { F-test }= \\
173.461 \mathrm{p}<0.01\end{array}$ & & 2.258 & 56.442 & $75.3 \%$ & 211.732 & $6 \mathrm{p}<0.01$ \\
\hline The bonds between this business and its employees are weak & 0.799 & & & & & \\
\hline Our employees have little or no commitment to this business & 0.758 & & & & & \\
\hline Factor $16:$ Esprit de corps $\alpha=0.50, F$-test $=14.641 p<0.01$ & & 1.715 & 42.874 & $63.6 \%$ & 83.485 & $6 \mathrm{p}<0.01$ \\
\hline $\begin{array}{l}\text { People in this business are genuinely concerned about the } \\
\text { needs and problems of each other }\end{array}$ & 0.710 & & & & & \\
\hline Working for this business is like being a part of a big family & 0.749 & & & & & \\
\hline People in this business feel emotionally attached to each other & 0.789 & & & & & \\
\hline $\begin{array}{l}\text { People in this business view themselves as independent } \\
\text { individuals who have to tolerate others around them }\end{array}$ & 0.568 & & & & & \\
\hline $\begin{array}{l}\text { Factor } 17: \text { Business performance } \alpha=0.901, \text { F-test }= \\
14.691 \mathrm{p}<0.01\end{array}$ & & 4.888 & 61.095 & $89.7 \%$ & 1233.140 & $28 \mathrm{p}<0.01$ \\
\hline Is it very easy to get your money back in this business & 0.583 & & & & & \\
\hline The profit of our business has increased & 0.853 & & & & & \\
\hline We have remarkable sales growth in our business & 0.844 & & & & & \\
\hline $\begin{array}{l}\text { The market share (the market size in relation to that of the } \\
\text { competitors) of this business has gone up }\end{array}$ & 0.733 & & & & & \\
\hline The sales volume has increased & 0.882 & & & & & \\
\hline The revenues of our business have increased & 0.866 & & & & & \\
\hline The quality of our products/services has improved & 0.549 & & & & & \\
\hline The financial position of our business has improved & 0.862 & & & & & \\
\hline
\end{tabular}

Table 6. Psychometric properties of customer satisfaction

\begin{tabular}{|c|c|c|c|c|c|c|}
\hline & $\begin{array}{c}\text { Factor } \\
\text { Loading }\end{array}$ & $\begin{array}{l}\text { Eigen } \\
\text { Value }\end{array}$ & $\begin{array}{c}\% \\
\text { Variance }\end{array}$ & KMO & $\begin{array}{c}\text { Bartlett's } \\
\text { test }\end{array}$ & $\mathbf{d} \mathbf{f}$ \\
\hline $\begin{array}{c}\text { Factor } 18 \text { : Customer satisfaction } \alpha=0.654, \text { F-test }= \\
\qquad 19.784 p<0.01\end{array}$ & & 2.341 & 59.009 & $71.2 \%$ & 217.220 & $15 \mathrm{p}<0.01$ \\
\hline We have more loyal customers than competitors & 0.666 & & & & & \\
\hline $\begin{array}{l}\text { We often receive complementary phone calls/letters from our } \\
\text { customers }\end{array}$ & 0.722 & & & & & \\
\hline $\begin{array}{l}\text { Our trade partners always praise us about our Product/service } \\
\text { quality }\end{array}$ & 0.664 & & & & & \\
\hline We hardly receive complaints about our product/service & 0.595 & & & & & \\
\hline We generate new customers in our business on a regular basis & 0.663 & & & & & \\
\hline $\begin{array}{c}\text { Customers of this business are happy with our } \\
\text { products/services and prices }\end{array}$ & 0.639 & & & & & \\
\hline
\end{tabular}

\section{Conclusion and Recommendation}

This study has examined the psychometric properties and the stability of the factor structure of MO scale items in Botswana among small service firms. The results demonstrate that MO scale items in Botswana have sound psychometric properties and a consistent factor structure. 
Although further research is necessary to replicate present findings and provide additional evidence of the psychometric competence. The Botswana version of MO scale items is thus posited to be an excellent instrument for the assessment of performance of small service firms .The instrument therefore exhibits both conceptual and psychometric equivalence by providing acceptable levels of reliability, variance extracted and both discriminant and nomological validity. The instrument in this empirical study will thus contribute to theory development and business performance among small service firms in Botswana. From a managerial perspective, the MO scale can be used to evaluate small service firms level of MO efficiency as a baseline measure.

\section{References}

Babin, J. B., \& Svensson,G, (2012). Structural equation modeling in social science research process, European Business Review, 24(4), 320-330. http://dx.doi.org/10.1108/09555341211242132

Bagozzi ,R. P., \& Foxall, G. R (1995). Construct validity and generalizability of the kirton adaption-innovation inventory. European Journal of Personality, 9(3), 185-206. http://dx.doi.org/10.1002/per.2410090303

Bearden,W. O., \& Netemeyer, R. G (1999).Handbook of Marketing scales:Multi item measures for marketing and Consumer Behaviour research, Sage,Newsbury Park,CA.

Blankson, C., \& Stokes, D, (2002). Marketing practices in the UK small businesses sector. Marketing Intelligence and Planning, 20(1), 49-61. http://dx.doi.org/10.1108/02634500210414774

Blankson, C., \& Cheng, J. M. S, (2005). Have small business adopted Market orientation concept? The case of small business in Michigan. Journal of Business and Industrial Marketing, 20(60), 317-330. http://dx.doi.org/10.1108/08858620510618156

Churchill, G. A .Jr, (1979) A paradigm for developing better measures of marketing constructs. Journal of Marketing Research, 16, 64-73. http://dx.doi.org/10.2307/3150876

Gerbing, D. W., \& Anderson, J. C, (1988). An updated paradigm for scale development incorporating unidimensionality and its assessment, Journal of Marketing Research, 25, 186-192. http://dx.doi.org/10.2307/3172650

Gilliam, D. A., \& Voss, K (2013). A proposed procedure for construct definition in marketing, $\begin{array}{lllll}\text { European Journal of } & \text { Marketing, } & \text { Vol.47 } & \text { No.1/2, }\end{array}$ http://dx.doi.org/10.1108/03090561311285439

Gray, B., Matear,S., Boshoff ,C., \& Matheson ,P. (1998). Developing a better measure of market orientation. European Journal of Marketing, 32(9-10), 884-903. http://dx.doi.org/10.1108/03090569810232327

Hunt, S. D, (1991). Modern marketing theory, Critical Issues in the Philosophy of Marketing Science, South Western Publishing Company, Cincinnati ,Ohio. 
Jaworski, B. J., \& Kholi, A. K, (1993). Market orientation antecedents and consequences. Journal of Marketing. 57(30), 53-70. http://dx.doi.org/10.2307/1251854

Mackenzie, S. B. (2003). The dangers of poor constructs conceptualization, Journal of the $\begin{array}{llll}\text { Academy of } \quad \text { Marketing 323-326. } & \text { 31(3), }\end{array}$ http://dx.doi.org/10.1177/0092070303031003011

Mowen, J. C., \& Voss, K. E. (2008). On building better construct measures: Implications of a general hierarchical model: Psychology and Marketing, 25(6), 485-505. http://dx.doi.org/10.1002/mar.20221

Nunnally, J. C. (1978). Psychometric Theory ,Mc Graw-Hill, Publishing, New York.

Rossiter, J. R. (2002). The C-OAR-SE procedure for scale development in marketing, International Journal of Research in Marketing, 19(4), 305-335. http://dx.doi.org/10.1016/S0167-8116(02)00097-6

Rust, R. T., \& Cooil, B. (1994). Reliability measures for qualitative data: theory and implications. Journal of Marketing Research. 31, 1-15. http://dx.doi.org/10.2307/3151942

Summers, J. O., (2001). Guide lines for conducting research and publishing in marketing: from conceptualization through the review process. Journal of the Academy of Marketing Science, 29(4), 405-415. http://dx.doi.org/10.1177/03079450094243

Teas, R. K., \& Palan, K. M (1997). The realms of scientific meaning framework for constructing theoretically meaningful nominal definitions of marketing concepts. Journal of Marketing. 61(2), 52-67.

Teo, TSH., \& King W. R., (1996). Key dimensions of facilitators and inhibitors for the strategic use of information technology. Journal of Management information systems, 12(4) 35-53. http://dx.doi.org/10.2307/1251830

Williamson, T. (1994). Vagueness,Routledge,London.

\section{Copyright Disclaimer}

Copyright reserved by the author(s).

This article is an open-access article distributed under the terms and conditions of the Creative Commons Attribution license (http://creativecommons.org/licenses/by/3.0/). 